\title{
The Elitism of Bertrand de Jouvenel. A Reinterpretation of Jouvenel's Political Theory Through the Elite theory
}

\section{Gabriele Ciampini}

University of Florence

Doi:10.5901/ajis.2013.v2n12p15

\section{Abstract}

This paper aims to reassess Bertrand de Jouvenel's political theory from an elitist perspective. Even if Bertrand de Jouvenel is commonly regarded as a liberal philosopher, I will however compare his thought with that of two main elitist thinkers: Gaetano Mosca and Roberto Michels. In the realistic vision of democracy developed by Jouvenel, popular participation is completely illusory. As Gaetano Mosca argued, any society is steadily ruled by an oligarchy. Not only cannot the entire electoral body fully participate in political life, but also MPs are deluded into thinking they can wield any kind of power. Moreover, they become, according to Jouvenel, selfreferencing institutions dominated by a political class which takes advantage of public services for its own interests. The analysis on modern political parties developed by Jouvenel is close to that of Robert Michels. They are viewed as powerful organizations whose aim is to perpetuate their own ruling class. Starting from this elitist analysis, Jouvenel focuses on concepts such as "common good" and "totalitarian democracy". The common good is viewed as a rhetorical expression to justify the implementation of welfare and redistributive policies whose consequence is the creation of a hypertrophic bureaucracy. The political oligarchy capitalizes on the whole situation in order to retain its own privileges.

\section{Introduction}

This paper aims to investigate Bertrand de Jouvenel's political theory from a critical perspective regarding the conventional theories his interpreters have put forward. Jouvenel has always been considered a minor scholar of Liberalism. (Mahoney, 2005; Dard, 2008).

If one analyses his writings, one realises that Liberalism certainly plays a significant role in Jouvenel's philosophical and political vision, but it is also fostered by other theoretical elements from different intellectual approaches. This short essay aims to provide a more complete understanding of his thought, showing that he developed a political theory that was in some ways very close to that of the theorists of Elitism. In this contribution, I will then retrace some common ground between Jouvenel's thought and that of Gaetano Mosca, Vilfredo Pareto and Robert Michels.

Raschi (2008) affirmed that: «Perché si possa parlare di Potere, dunque, è necessario che siano presenti contemporaneamente diversi elementi. Da un lato, deve esistere un «corpo permanente» che detenga le leve della coercizione. Devono cioè esistere degli uomini, poco numerosi , che agiscono su altri uomini, ben più numerosi» (Raschi 2008, p. 20)

Jouvenel inherited his conception of democracy from his uncle Robert de Jouvenel, who, in the pamphlet La République des camarades (1914), stands for an elitist conception of society. In this pamphlet, Robert de Jouvenel develops a totally realistic theory of democracy. The idealist vision considers participation s a central concept in such a system of government.

In fact, Robert de Jouvenel tries to demonstrate that democracy does not only rely on the participation of all citizens, but also consists in delegating to representatives the process by which decisions - applied to everyone - are taken. However, parliaments do not always reflect the popular will: as time goes by, the political class becomes increasingly self-referring, thus changing the democratic political system into a 'republic of comrades'. As we shall see, this conception of democracy presents common features with that developed by Bertrand de Jouvenel.

As affirmed by Richard: "La République des Camarades est avant toute une description des moeurs politiques du début du vingtième siècle. Elle vient synthétiser le phénomène d'autonomisation du personnel politique, elle montre l'affirmation d'un métier en décrivant les filières et la formation d'une profession parlementaire en pleine expansion" (Richard 2004, p. 48).

In fact, Robert de Jouvenel (1914) defends elitist views "le groupe n'est pas une organisation politique mais une union corporative. II n'est pas créé pour faire triompher une doctrine, mais pour permettre à certain nombre d'individus d'arriver sans se bousculer" (Jouvenel 1914, p. 71). 


\section{Popular Sovereignty and Totalitarian Democracy}

The purpose of this paper is to analyse more precisely the critique of democracy that Bertrand de Jouvenel develops. Apart from the critique of contemporary regimes, Jouvenel faces simultaneously the problem of 'common good', which can be understood through the concept of "general will": after a popular consultation, the majority will automatically become the general will. This is the accusation that Jouvenel levels at democratic political systems: the will of the majority tramples the freedom of minorities. This is due to the fact that the most popular opinion, that is to say the one adopted by the majority, is actually the best. The general will "ne serait pas la volonté de tous, parce que tous n'ont pas l'intention civique, mais ceux qui ne l'ont pas, ou en qui elle est trop faible pour l'emporte sur le souci de leur bien propre, et pour leur révéler le bien commun, donc les «mauvais citoyens», se trouveraient impuissants en présence des «bons». En effet, chacun d'eux ne pensant qu'a soit, cette particularité de leurs préoccupations éparpillerait les volontés des mauvaises citoyens, lesquelles se trouveraient par cette dispersion, faibles en toute occasion contre la volonté des bons citoyens, compacte, cohérente et parée des prestige de la vertu".(Jouvenel 1955, p. 139)

In contemporary democracy, the notion of common good is seen by Jouvenel as a rhetorical aim to justify an oppressive bureaucracy.

These issues, however, appear problematic only when the question of democracy is tackled.

As we have already said, modern democracy is, for Jouvenel, an ideal doomed to failure: there is no way to check the real participation of citizens in public life, since the decisions are taken by a minority of individuals who, unlike what happened in the premodern era, justifies the policies adopted by claiming to have the 'people', mistakenly regarded as a homogeneous entity, on their side.

As Rinaldini affirms,

Quando la Rivoluzione francese proclama il principio della sovranità popolare, non è che per delegarla immediatamente all'Assemblea nazionale e al re; e una volta abolita la monarchia, il nuovo parlamento deve assumere una fisionomia radicalmente diversa dai "parlamenti» che l'hanno preceduto: esso non prosegue la rappresentanza degli interessi particolari che vivono nella società ma si sostituisce alla rappresentanza monarchica come incarnazione della totalità della nazione. Esso si presenta non come un'assemblea di delegati ma come il popolo stesso riunito in assemblea: tanto che in esso la decisione deve formarsi, come prescrive Sieyès fin dal settembre dell'ottantanove, secondo la modalità con cui si forma la volontà generale nel popolo riunito in assemblea quale è descritto nel Contratto sociale di Rousseau. (Rinaldini 1997, p.39)

Jouvenel speaks explicitly of a totalitarian drift of democracy. The European representative assemblies before the French Revolution aspired to represent the various facets of society. For example, every economic corporation had its own representatives. The ruler was supposed to mediate between the different social issues to develop common solutions. Only in this way, by taking into account the profound heterogeneity of the social body, could the common good be grasped.

The characteristic of pre-modern societies consists in the fact that no social group aspired then to consider itself the spokesman of society. With the advent of democracy as we know it today, sovereignty becomes the prerogative of a selected group of individuals claiming to administer public affairs in the name of 'the people', which is seen as a homogeneous entity. Parliaments thus become the only institution capable of acting on behalf of the general public, while the role of the sovereign is inevitably devalued. He/she no longer has to come to an agreement with the various social components.

Mais lorsque la préférence donnée à l'assemblée sur le souverain l'a fait investir, elle seule, de la puissance législative, comme seul représentant de la Nation, on n'a point vu qu'on changeait par là son caractère et que son attitude devait changer.

Au lieu d'être juxtaposition d'intérêts divers, représentantes par des mandataires tenus impérativement, elle devenait représentation totale de la totalité nationale, comme il fallait bien qu'elle fût dans un système de pensée qui la chargerait de faire des lois au nom de la Nation.

Ce qu'assurait l'ancienne constitution, c'est que qu'une loi, proposée par la Pouvoir au nom de l'intérêt public, ne pouvait devenir loi qu'autant qu'elle aurait obtenu l'assentiment des intérêts divers qui sont dans la Nation. (Jouvenel 1945, p. 391)

Then, the parliament inherited the mission and needs of the monarchy. At this point, the sovereign has not disappeared: he/she has simply become the Parliament that confers the right to represent the whole of society. The multiple voices that characterized it have disappeared. 
As I stated earlier, since Parliament is the only institution supposed to legislate, natural law loses its importance. Up to that point, it had been such a law which had governed life in society, preventing the Power from trampling individual freedoms. What matters is Parliament's sovereignty legitimated by the popular vote. It may also enact unjust laws that sacrifice individual rights in the name of social reforms.

In this sense, he speaks explicitly of "totalitarian democracy" (Jouvenel 1945, § 14).

He emphasises the concept of general will. It is the central point for the understanding of democracy as an authoritarian phenomenon. Insisting on the social model in the pre-modern era, Jouvenel maintains that the various components of society were engaged in asserting their own interests, even if that 'competition' did not absolutely undermine the cohesion of the community.

La société offre à l'observateur une foule immense d'individus animés de volontés particulières, et que la diversité des caractères, des rôles et des situations groupe naturellement en sortes de corps à chacun desquels correspond un intérêt, général par rapport à ses membres particulier au regard de la Société. Ces volontés individuelles, ces intérêts fractionnaires forment les réalités élémentaires de la vie sociale. Sans doute elles sont en lutte continuelle mais cette lutte, pourvu que certaines règles la régissent, est l'âme même de la Société. (Jouvenel 1945, p. 419)

However, Power always had the temptation to be the sole repository of the general interest, to be aware of the most appropriate policies to be adopted. Jouvenel speaks explicitly of the «carachtère d' infallibilité» (Jouvenel 1945, p. 419) - which characterizes the State from those who represent it - as the sole guarantor of the common good.

While in the monarchy the sovereign was distinct from the people and the interests of its members:

La volonté royale était connue pour celle du personage couronné, de son favori , de son ministre: elle était par là humaine et particulière, de plain-pied avec les autres volontés. La volonté du Pouvoir démocratique se dit générale. Elle accable chaque individu sous le poids de la totalité des individus qu'elle représente, et opprime chaque intérêt particulier au nom d'un intérêt général qui s'incarne en elle. (Jouvenel 1945, p. 419)

Power's will in a democratic system is called 'General'. Jouvenel points out that the State can aspire to defend the general will only in the case of very small communities, such as the city-states of ancient Greece. The inhabitants of these communities were united by similar social conditions. It differed from the modern national community, composed of communities that are different from each other in many ways.

Often, the leader, who is democratically elected, not only pretends to represent the whole society, but also wants to delete the various differences that constitute the wealth of a society: all citizens must simply have the same interests and the same needs. Power aims at the destruction of small local communities, which are homogeneous in terms of language and culture. Jouvenel, to support this thesis, quotes various historical examples, from the National Convention after the French Revolution that condemns the federalists, to the British Parliament that stifles any tendency for autonomy expressed by Ireland.

Even here Jouvenel clearly asserts that modern democracy is nothing more than an illusion justifying violent practices of repression: it is precisely in small communities that citizens can actively participate in political life, without being overtaken by oligarchic groups that are self-proclaimed defenders of the public interest:

Cette hostilité à la formation de communautés plus petites ne se concilie pas avec la prétention d'instaurer le gouvernement du people par lui-même, puisque manifestement ce gouvernement est d'autant plus une réalité qu'il s'exerce dans des communautés plus petites. C'est alors seulement que les citoyens peuvent choisir directement leurs magistrats car ils les connaissent par expérience. (Jouvenel 1945, p. 421-422)

Jouvenel explores the concept of totalitarian democracy by speaking of «absolutisme de la volonté souveraine» (Jouvenel. 1945, p. 119). He starts by arguing that all members of a society tend, more or less, to be subject to common rules. However, this premise does not mean that to be ruled by a tyrannical regime is acceptable or natural. Jouvenel, as in other works, is the defender of a conception of society that is not simply individualistic. He argues that unity and cooperation are necessary among individuals, but that these factors must not result in an oppressive bureaucratic state:

L'adjectif «absolu», couramment employé aujoud'hui avec une valeur de blâme sans valeur de désignation précise, a en droit un sens bien défini : il traduit la locution «legibus solutus», émancipé des lois. Or, qui est le plus émancipé des règles? celui qui est moralement tenu de les observer en l'absence de sanctions, ou celui qui est à tout moment maitre de les changer? c'est évidement le second. La démanche historique vers une souveraineté indéfiniment législative a donc été une démanche vers l'absolutisme, et ce que nous appelons l'époque de l'absolutisme n'a été en fait que la période de sa gestation. (Jouvenel 1955, p. 121) 
The citizen can definitely use his strengths and abilities as he wants. But the laws of the society in which he lives, impose restrictions and obligations. The bourgeois sees his freedom constrained. This in itself is not a bad thing, says Jouvenel, as no society has ever been unregulated. In feudal societies, behaviours were ruled by natural law to which the sovereign was also subjected. As we have already said, he/she was subject to ethical constraints, derived from natural law.

The aim of Jouvenel is to understand what constitutes the absolutism of the sovereign will.

The latter approach, in which both Du Pouvoir and De la Souveraineté are strongly criticized, is seen as a rhetorical device. Jouvenel says that the main problem at the roots of the concept of "general will" is the misconception of the people. As we have said, the population is seen as a homogeneous entity which delegates power to the person or group by which it wants to be governed. The main problem lies in the fact that the rulers should realize the people's interest, or the general interest. But only the individual knows what his own interest is, which is different from the interest and expectations of another. The principle of the general will prevails on the individual citizen's will.

C'est une erreur substantielle de considérer le Peuple comme une personne simple, à la fois gouvernante et gouvernée : m'attribuer à moi sujet, la volonté d'une majorité du corps législatif ou d'un de ses ministres, n'est pas une moindre fiction juridique que de m'attribuer la volonté du monarque ou d'un de ses ministres. Dans l'un ou l'autre cas, il est permis de me dire qu'il s'agit de la Volonté Souveraine à laquelle je dois me soumettre, mais dans l'un aussi bien que dans l'autre, il est faus de me dire: "C'est toi qui as voulu.» On peut tout au plus me dire: "Tu dois agir comme si c'était toi qui l'avais voulu». (Jouvenel 1955, p. 122)

Jouvenel denounces the fact that the people are granted qualities which are the exclusive privilege of individuals, such as rationality and the ability to discern right from wrong. In fact, in any institutional arrangement, the people must be taught by individuals who must be «exhortés et éclairés» (Jouvenel. 1955, p. 123). They are highly trained to manage public affairs. Here, as in other passages of his works, Jouvenel's thought was affected by elitism.

Claiming that 'the sovereign will must tend to the public good', presupposes that they are both desired and known. The common good is to find solutions that meet the demands arising from different segments of society. So the citizen who wants to take care of public affairs must put aside his own particular and selfish interests.

Jouvenel points out that popular sovereignty is apparently respected by politicians, by arguing that democracy is inherently authoritarian.

First, the people are not sovereign, because they do not really have the right to make laws. As has already been argued, the legislative power is delegated to the Parliament. Citizens have the sole right to elect their own representatives, who will not be subject to any restrictions. They will form a self-referential oligarchy that arrogates to itself the right to decide what the common good is:

Ainsi, le prétendu "Pouvoir du Peuple" n'est relié au peuple que par le cordon ombilical très lâche des élection générales ; il n'est effectivement qu'un «Pouvoir sur le peuple. Mais autant plus grand qu'il s'autorise précisément de ce cordon». (Jouvenel, 1945, p. 425-526)

\section{The Problem of a Ruling Elite in Democracy}

As has already been said, Jouvenel's critique of democracy rests on the presence of a dominant group that claims to represent the community. Democracy is not about majority rule (although in compliance with the minority), but a small elite of rulers who claims to represent the entire electorate.

La réunion du Parlement avait donc comme caractère originel et essentiel d'être la convocation des puissances grandes ou petites auxquelles le roi ne pouvait ordonner et avec lesquelles il lui fallait négocier.

Le Roi anglais siégeant en son Parlement, ou le Roi française en ses Etats Généraux, c'est le congrès des puissances de la nation, où la puissance publique rencontre les puissances particulières, où l'intérêt général, qui s'incarne dans le Roi, traite avec les intérêts fractionnaires, qui paraissent «en personne» ou par représentants. (Jouvenel, 1945, pp. 389-390)

Jouvenel therefore states that Power is forced to constantly debate with the other representatives of society, in order to address political questions.

A radical change in this state of affairs is when the sovereign, for example Louis XIII and Charles I, establishes a tax without having obtained the aristocrats' consent. The sovereign no longer receives gold as a subsidy paid by an assembly that is representative of the various social interests, but will retain the right to know what is the common good of society regardless of the diversity of its members. Pretending to know the common good of a society without taking into 
account its structural complexity became structural after the French Revolution and the advent of democracy.

The difference between absolute monarchy, in which the sovereign themselves is the defender of the general interest, and parliamentary democracy, is not substantial: in both cases the intermediate powers and the various interest groups are excluded from the public discussion.

Jouvenel denounces the representatives' myopia that prevented them from realizing the change that had occurred: the Parliament has ceased to be the place of encounter-clash between the various individual interests, ending up by becoming an autonomous institution from society.

Mais que ces intérêts divers, en cette qualité, proposent la loi, ce serait illogique, puisque la loi tend à l'intérêt général. Devenant auteur des lois, l'assemblée ne pouvait l'être qu'en vertu de l'idée nouvelle qu'elle représentait la Nation comme Tout et dans son intérêt général, c'est-à-dire ce que le Roi avait auparavant représenté. Mais c'était un changement de son essence, marqué par la neuve liberté des représentants à l'égard de leurs commettants, liberté sur laquelle les doctrinaires du nouveau système on si vigoureusement insisté.

Ils ne prenaient pas garde qu'unifié, affranchi, rendu suprême comme auteur principal, qui tendait à devenir auteur unique, de la loi, le Parlement ne pouvait conserver le même comportement qui le caractérisait, divers, lié, et sans pouvoir propre. (Jouvenel, 1945, pp. 391-392)

With the formation of this self-referential oligarchy, the increase in the State's Power seems limitless. The representation of interests that must be manifested in Parliament has disappeared. It was the latter, which now, with no real social references, relied on the representation of a non-existent homogenous 'people', with well-defined interests. It is from this state of affairs that civil society is crushed under the weight of bureaucracy.

Jouvenel emphasises two aspects of power in democratic regimes: first, it is controlled by the Parliament, which in turn is operated by a committee inside it. This means that even individual MPs have substantial margins of autonomy, because they have to follow the directives of an even smaller number of individuals. The second aspect concerns the social background of MPs: over time, they come, to a certain extent, from the lower strata of society.

The realist conception of democracy developed by Jouvenel has many points in common with that of Gaetano Mosca:

Fra le tendenze ed i fatti costanti, che si trovano in tutti gli organismi politici, uno ve n'è la cui evidenza può essere a tutti facilmente manifesta: in tutte le società, a cominciare da quelle più mediocremente sviluppate e che sono appena arrivate ai primordi della civiltà, fino alle più colte e più forti, esistono due classi di persone: quelle dei governanti e l'altra dei governati. la prima, che è sempre la meno numerosa, adempie a tutte le funzioni politiche, monopolizza il potere e gode $i$ vantaggi che ad esso sono uniti; mentre la seconda, più numerosa, è diretta e regolata dalla prima in modo più o meno legale, ovvero più o meno arbitrario e violento, e ad essa fornisce, almeno apparentemente, i mezzi materiali di sussistenza e quelli che alla vitalità dell'organismo politico sono necessari. (Mosca 1966, p. 61).

Mosca, harshly criticized democracy. As stated by Bobbio (1966), he accused the «democrazia formale di aver spalancato la porta alla democrazia sostanziale» (Bobbio, 1966, p. xxix).

The consequence of democracy and of the growing participation of classes which until then had been excluded from public life, would be the advent of collectivism in the oligarchic management of politics and economics. For Mosca, every society is structurally controlled by an oligarchy. But in some cases, in a democracy, or an oligarchy that, paradoxically, is likely to be more despotic because, «con la partecipazione delle masse al potere politico avrebbe finito per fare trionfare una forza politica sola e affrettato quella che fu chiamata, nel ventennio tra le due guerre, l'era delle tirannie» (Bobbio 1966, p. xxx).

Jouvenel affirms in Du Pouvoir that the conviction that Parliament is an expression of the general will, is due to a «fiction audacieuse» (Jouvenel, 1945, p. 409): Parliament has begun to consider the People (with autonomous political subjectivity) an assembly. Then, the Executive, once given the Parliament's legitimacy, is called 'government of the People'.

The idea of parliamentary sovereignty has been modified in favour of the new political class. Jouvenel also describes the intermediate step for this change in European political culture: in the Nineteenth Century, Members of Parliament were elected democratically, but all of them came from high social classes. Their education was excellent, they knew the complexity of society and were not willing to give in to populism. These politicians had the same role as the aristocracy. Considering this, it is not surprising for Jouvenel that there is no genuine popular participation in the democratic process. Every government is run by an élite; but if it fails to prevent the advance of Power while respecting any political actors, then the élite will perform its political duties. 
Evelyne Pisier in this regard expresses Jouvenel's thought clearly:

\begin{abstract}
Inégalitaire, la societé l'est par nature, cette, inegalité n'est pas «naturellement» juste: l'autorité est un fait naturel, mais ses détenteurs sont tenus de mener à bien le rôle social, économique, politique et moral qui la justifie.

Le lois naturelles ne sont donc pas les seules lois qui président à la sélection e tau maintien d'une aristocratie. [...]

Éducation, sacrifice, sens du devoir: l'élite, pour Bertrand de Jouvenel, est d'abord morale. (Pisier, 1967, p. 60-61)
\end{abstract}

The representation of local interests was guaranteed by the small size of the constituencies. According to Jouvenel, if citizens can know their candidates personally, then the competition will be from the bottom up and the choice of politicians will be based on their merit. When the people were still considered as an indistinct mass, the voters, knowing what their interests were, elected officials on the basis of their abilities: "Tant que le people assemble par circoscriptions pour nommer ses representantes nationaux regarde au merite personnel et non à l'opinion affichée, l'assemblée est constituéepar une élite de personnalités indépendantes" (Jouvenel 1945, p. 438).

Jouvenel examines the mechanisms by which the political class is selected. For this, he investigates the role of political parties in the formation of the ruling class in the Twentieth Century. The parties are no longer the tools of representation, but they have increasingly become distant from the electoral body, growing into oligarchies. If Parliament had the whole Power, the representatives would not feel so compelled to defend anyone's interests in society, but to organise themselves into groups separated from each other without the slightest desire to work together in order to find solutions that could comply with the general interest. Parliamentary debates, then, are no longer characterised by pragmatism and the desire to solve real problems; they have become a purely ideological confrontation between groups fighting for Power.

Jouvenel affirms that «Le Parlement n'est plus alors une assemblée souveraine où une élite d'hommes indépendants, comparent des opinions libres et parviennent à une décision raisonnable. Ce n'est que la chambre de compensation où les partis mesurent l'un contre l'autre leurs paquets de votes.» (Jouvenel 1945, p. 445)

This change was described to the electorate as something positive: before the voter had to vote for a person in accordance with to his/her skills. By relying on only one person, the voter "surrendered" their own sovereignty.

Through the election of MPs on the basis of abstract ideals, the voter should have been freer, more capable of impacting on the decision-making process. Jouvenel strongly criticises this view, arguing that if the voter's choice is based on abstract values without taking into account his/her own interests, he or she allows the political class to emancipate itself from the will emerging from below.

In fact, Jouvenel notes that there has been, in the Twentieth Century, a curious reversal: it seems that the voters do not choose the politicians, but on the contrary, that the latter are imposed on voters. By referring to political ideologies, the leadership of a party can impose on voters their political orientation and push them to elect candidates who do not deserve to be elected: "Par le prestige de ses leaders et la popularité de ses principes, le groupe fait triompher des candidats qu'il a choisis en raison de leur valeur proper que de l'obéissance qu'ils promettaient; ils seront d'allieurs d'autant plus fidèles qu'ils sont plus incapables d'une carrier autonome" (Jouvenel 1945, p. 439).

The other result, or consequence, of this overturning of the roles of voters and the political class, is the loss of importance of the voter, who is seen as important by the parties only according to the influence he or she can have in an electoral competition. When England extended the right to vote in 1832, the British parties immediately enrolled their voters in special registers, in order to find them and solicit them, fearing they might not cast their vote in the next election: "C'était moins le spectacle d'un people exerçant fièrement ses droits de citoyen que celui de deux factions racolant par tous le moyens les suffrages qui pouvaient donner le Pouvoir" (Jouvenel 1945, p. 440).

Jouvenel focuses on an analysis of the selection of the political class. During the election campaign, the candidate must make himself known. But the 'political machine', that is to say, the party, makes the main efforts for this purpose. Actually, the voters do not rationally decide which candidate is closer to their own interests because the party machine has already selected the candidates for them. Obviously, it does not grant the elected candidate any freedom. Because the MP owes his/her election to the party, he/she will act according to the party's will.

As has already been said, the outcome of this selection process consists in lowering the quality of the political class. Inasmuch as the loyalty to the apparatus is the only thing which counts, Parliament becomes the place of pointless competition amongst factions.

Here, Jouvenel's vision is very close to that of Robert Michels (1915). Thanks to an initial ideological proximity to the German Social Democratic Party (SPD), Michels undertook a deep study of the oligarchical tendency within each political formation: "The formation of oligarchies within the various forms of democracy is the outcome of organic necessity, and consequently affects every organization, be it socialist or even anarchist. Haller long ago noted that in 
every form of social life relationships of dominion and of dependence are created by Nature herself. The supremacy of the leaders in the democratic and revolutionary parties has to be taken into account in every historic situation present and to come, even though only a few and exceptional minds will be fully conscious of its existence. The mass will never rule except in abstracto». (Michels, 1915, p. 402)

Michels highlights the characteristics of modern political parties and their leaders. Leaders are characterised by the creation of advantageous positions that make them indispensable. Sola (2000), p. 98) even states that: «[for Michels] la stabilità dei leaders non dipende soltanto dalla loro automatica rielezione, ma anche da alcune cause «tecniche». Fra le principali Michels enumera: il cumularsi delle cariche nelle loro mani, la capacità di valersi dell'apparato organizzativo, una competenza di carattere amministrativo. Questi elementi di supremazia, cui si affiancano la gestione centralizzata delle risorse finanziarie, il controllo sulla stampa, la monopolizzazione della propaganda, configurano una sorta di competenza organizzativa che rende i dirigenti indispensabili» (Sola 2000, p. 98).

Co-option is one of the most important features of political classes. It happens when the leaders, in an attempt not to lose their power, want to eliminate any potential competition. They admit into the party elite only those potential executives who share the policies pursued by the leaders.

Political leaders' increasing power ensures that they emancipate themselves from the electorate they are supposed to represent. «ll partito diventa quindi una vera e propria casta che, all'interno del partito di massa, riproduce anche in questo contesto la perenne divisione tra governanti e governati, trasformando i delegati in "sovrani» e i gestori del partito in "padroni»»" (Sola 2000, p. 101).

In this situation it becomes possible to form a true government: Jouvenel argues that the principle of separation of power is actually unrealised. The Government should be autonomous from the Parliament if it wants to enjoy any substantial autonomy. The executive, which should be an expression of the popular will, is in fact directed by parties' leaders supporting it in Parliament.

Du Pouvoir explicitly deals with powerful party organisations which can have a strong influence on the choice of the citizen. This happens not only because of the amount of money a party can rely on for a campaign, or because of its anchoring within a society. It happens because the arguments put forward to gather consensus are not based on a rational analysis of the situation, but on the voter's emotions. With this, Jouvenel highlights that the electoral success of parties is inversely proportional to their merits: they can be chosen for the ideology they support and not for the problems they solve, for their ability to entertain relationships of patronage with people who then reward them by voting for them. Furthermore, the election based on partisanship triggers the formation of a "group spirit" which can result in real camaraderie.

The division of society into antagonistic factions does not give rise to a cultural and political growth of the citizens, but to a clamour of conflicting arguments in which the only thing that matters is to win against the other and not to find a common point of view.

Si la faculté raisonnante n'est pas très exercée dans la majorité d'une population, tous les hommes au contraire son capables d'émotion. Et c'est donc sur ces émotions qu'il faut agir. Susciter en sa faveur la confiance, l'espoir, l'amour et, contre le concurrent, l'indignation, la colère, la haine, voilà le secret du succès. II est complet lorsqu'un public applaudit un discours qu'il ne peut entendre et couvre par des trépignements la replique de l'adversaire. (Jouvenel 1945, p. 444)

In the second half of the Twentieth century, the relationship between citizens and political parties was almost always characterised by irrational approaches. Rarely was a politician elected by the electorate because he was judged worthy on the basis of a decision taken rationally.

For Jouvenel, in modern democracies, the scarce use of reason to deal with political issues is one of the causes of the concentration of power in the hands of a minority. Democracy, in theory, should be an exercise in dialogue in a spirit of mutual respect; in practice it is a means of dividing the citizens for the benefit of competing elites.

The concepts of 'general will', 'totalitarian democracy' and 'ruling oligarchy' in this case are inextricably linked, especially if such a connection is analysed from the perspective of historical experiences such as the French Revolution and the Jacobin Terror. The general will is seen by the oligarchy holding the power as an end to which the people are naturally pushed. But since it is impossible for all citizens to find an agreement and conform to the general will, only the social body's majority, adhering to the ideals espoused by the ideologically dominant elite, will be considered "the people". Individuals who do not agree with the majority are not only excluded from the decision-making process, but are also considered no longer part of the same community. They are seen as foreign bodies.

The general will is obviously not predetermined, but it is 'interpreted' arbitrarily by the dominant group. In fact, the people should get out of the bondage in which they are held, through the propaganda and the biased education they 
receive from a so-called "enlightened vanguard" who tell them to follow their intimate - but until then unknown - propensity to break free from the chains of a feudal slave system they have been subjcted to for a long time. One can notice here the presence of a strong paternalism: in short, for Jouvenel it is clear why the lower classes, with the illusion of becoming free, unwillingly pass from one despotic regime to another.

The Jacobins, the architects of the Reign of Terror, were convinced that it was not necessary to reform society in order to make it more egalitarian. Their goal was the complete purification of society to reach perfection. But how could one justify seizing power? The revolution resulted in the seizure of power without the consent of the people. But the people were not yet quite ready to understand the good intentions of the Jacobins. They "were generally too slow to recognize that their rights were being violated, and still slower in rising against oppression, lulled and deceived as they were by the oppressors" (Talmon 1952, p 209). The Jacobins believed that the revolution would have right from the start the approval of the masses, since a radical change in a context of exploitation was very likely to win the favour of the subordinate classes.

Then, there was "an authorization and challenge in the very order of things. Society was founded to secure happiness for all. As long as this had not been donem as long as there existed inequality, and consequently oppression, and as long as men's faculties and freedom were being stifled, there was a permanent right to Revolution" (Talmon 1952, p. 209-210).

The Jacobins, therefore, as did all those who sought a radical change of society by relying on an alleged general will, considered the people the depositary of positive values (equality, social justice, etc.), even if they were not aware of it.

The idea of an assumed preordinated will, which has not yet become the actual will of the nation; the view that the nation is still therefore in its infancy, a "young nation", in the nomenclature of the Social Contract, gives those who claim to know and to represent the real and the ultimate will of the nation - the party of the vanguard - a blank cheque to act on behalf of the people, without reference to the people's actual will. (Talmon 1952, p. 48)

The revolutionary vanguard are none other than an elite that is imposed on society. It is useful to analyse the concept developed by Talmon of 'totalitarian democracy' to fully understand the criticism of democracy developed by Jouvenel. According to the Jacobins, once the revolution has been accomplished and a revolutionary committee has been established (with the task of organizing popular assemblies), the whole previous legal system falls. Now everybody lives in a society that, at least in theory, is based on the equality of all individuals. In reality, however, it is necessary to have a group of 'wise men' to help the people to understand what the general will is.

The real people, or rather their leadership, once triumphant in their insurrection, become Rousseau's Legislator, who surveys clearly the whole panorama, without being swayed by partial interests and passions, and shapes the "young nation" with the help of laws derived from his superior wisdom. He prepares it to will the general will. First comes the elimination of men and influences not of the people and not identified with the general will embodied in the newly established Social Contract of the Revolution; then the re-education of the young nation to will the general will. (Talmon 1952, p. 49)

This analysis constitutes a significant contribution to the understanding of Jouvenelian thought. One can say that, in the Jacobin thought, the people are free to participate in political life if it conforms to the ideals of a small caste of 'wise men'. The right of citizens to contribute to the decision-making process is flawed if one starts from the enhanced importance ascribed to a selected group of individuals, who have a right and a duty to 'educate' the rest of the social body. Therefore, for Jouvenel, there is no real desire to improve the living conditions of the masses, but simply to influence them depending on the interests of the elite.

\section{References}

Dard, O. (2008), Bertrand de Jouvenel, Perrin, Paris.

Jouvenel, B. de (1945), Du Pouvoir, Librerie Hachette, Paris.

Jouvenel, B. de (1955), De la souveraineté, Génin, Paris.

Jouvenel, R. de (1914), La républiques des camerades, Bernard Grasset, Paris.

Mahoney, D. (2005), Bertrand de Jouvenel: Conservative Liberal and the Illusion of Modernity, ISI Books, Wilmington, Delaware.

Michels, R. (1915), Political Parties: A Sociological Study of the Oligarchical Tendencies of Modern Democracy, The Free Press, New York.

Mosca, G. (1966), La classe politica, Laterza, Roma-Bari. 
Pisier, E. (1967), Autorité et liberté dans les écrit politiques de Bertrand de Jouvenel, Presses Universitaires de France, Paris.

Raschi, F. (2008), Autorità e potere. II pensiero politico di Bertrand de Jouvenel, Rubbettino, Soveria Mannelli.

Richard, S. (2004), Robert de Jouvenel: un élitisme à la française in Henry, Robert et Bertrand de Jouvenel. Crise et métamorphoses de l'État démocratique, 1900-1935, Presses Universitaires de Limoges.

Rinaldini, F. (1997), Bertrand de Jouvenel. Introduzione alla teoria politica, Edizioni Scientifiche Italiane, Napoli.

Sola, G. (2000), La teoria della élites, II Mulino, Bologna.

Talmon J. (1952), The origins of totalitarian democracy, Secker and Warburg, London. 